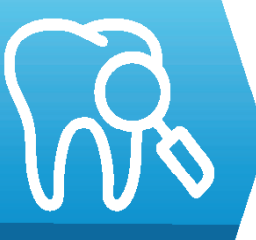

DENTAL MEDICINE
1) Prosthetics Technologies and Dental Materials Department, Faculty of Dental Medicine, "Carol Davila" University of Medicine and Pharmacy, Bucharest, Romania

2) Embryology Department, Faculty of Dental Medicine, "Carol Davila" University of Medicine and Pharmacy, Bucharest, Romania

3) Oral Health and Community Dentistry Department, Faculty of Dental Medicine, "Carol Davila" University of Medicine and Pharmacy, Bucharest, Romania
DOI: $10.15386 / \mathrm{mpr}-1518$

Manuscript received: 05.07.2019

Accepted: 02.09.2019

Address for correspondence:

andreea.didilescu@umfcd.ro

\title{
Experiential learning for adolescents - results from a 2-year school-based oral health educational program
}

\author{
Roxana Romanita Ilici ${ }^{1}$, Andreea Cristiana Didilescu ${ }^{2}$, \\ Ruxandra Sfeatcu ${ }^{3}$, Mihaela Adina Dumitrache ${ }^{3}$
}

\begin{abstract}
Background. For oral health promotion, teenagers represent an important target group, given that appropriate personal oral hygiene and dietary behaviors are established during this period of life. Experiential learning is an educational approach where learning comes through experience.
\end{abstract}

The aim of the Erasmus+ project "Youth Community-Based Oral Health Learning Model" was to assess the influence of a school-based experiential education program on oral health status, knowledge and behavior among a group of schoolchildren in Bucharest.

Methods. This longitudinal interventional study started in 2015 and enrolled 120 adolescents from three public schools. At baseline, all subjects were clinically examined and received a questionnaire. They were split into two groups: the test group received three experiential lessons and control group benefited from a demonstration of tooth brushing technique.

Results were presented for the test group, 76 schoolchildren, divided in two age groups: 13-14 years and 15-16 years. More children from the test group adopted twice-daily tooth brushing compared to the control group. The level of knowledge was good, but the role of a noncariogenic diet must be emphasized.

Conclusions. The oral health program had positive effects on oral health knowledge and behavior among adolescents. The present study indicated that intervention using experiential learning involving dental students was effective in increasing oral health attitudes and behavior among adolescents from 13-16 years of age included in the study.

Key words: experiential learning, knowledge, behavior, adolescents

\section{Background}

The objectives for oral health of the World Health Organization (WHO) for 2025 are to reduce the proportion of youth with dental caries and periodontal diseases and to increase to $75 \%$ of the youth population having enough knowledge about etiology and prevention of oral diseases [1].

Experiential learning (EL) is a learning style where education comes through experience, as it was defined by David Kolb [2]. Recently it has been implemented in oral health education with good results in improving health knowledge, behavior and attitudes [3].
In terms of oral health promotion, there is a need to give priority to the teenagers due to the fact that during this period of life it is very important to acquire healthy behaviors and useful medical information [4]. For oral health programs, schools are behaviors supportive environment to promote oral healthy habits or to change unhealthy habits among adolescents, by experiential learning and appropriate motivation [5-7].

The project focused on implementing and promoting oral health education, training and communication programs and on the participation of 
dental students in experiential learning education lessons in school-based communities [8]. All partners combined their broad knowledge and expertise in oral health education for youth and created this EL program among adolescents [9].

Currently, experiential learning applied in adolescents' communities (school-based oral health education programs) proved to be more successful than traditional learning, especially for improving health behavior (dental hygiene practices) [10].

Thus, the aim of the study was to assess the effect of three experiential education lessons on oral health knowledge and behavior among a group of schoolchildren from Bucharest.

\section{Methods}

Out of the 120 students enrolled in the study, the experimental education lessons were applied to the experimental group, 76 adolescents divided into 2 age groups: 13-14 years and 15-16 years old from 2 schools in Bucharest.

Oral health $(\mathrm{OH})$ education lessons were structured on David KOLB's experimental learning model with four elements: concrete experience, reflective observation, abstract conceptualization and active experimentation and have been developed by the members of Oral Health and Community Dentistry Discipline and their partners within the project [8]. Dental students were trained and then applied these $\mathrm{OH}$ lessons in schools, supervised by university teachers, in classrooms, in small groups of schoolchildren.

The three $\mathrm{OH}$ lessons were held at 8 months intervals: the first referred to causal chain of the caries and appropriate tooth brushing technique, the second focused on role of the diet in oral health and the third lesson addressed the importance of referral to the dentist in order to maintain good oral health [9].

The first stage of the study consisted of the initial assessment of the pupils' knowledge and behavior towards oral health, through the distribution of a questionnaire. After each education lesson, the schoolchildren completed the same questionnaire again.

Prior to the beginning of the study the ethical approval from the Ethics Commission of UMP "Carol Davila" was obtained. Parents gave their written consent for the participation of the children in the study.

\section{Results}

I. Results regarding oral health behavior changes after every education lesson

Regarding the personal oral hygiene behavior, the correct brushing frequency increased in both age groups following the three lessons of education (Table I).

Concerning cariogenic food consumption, it was observed that the frequency of consumption of biscuits and cakes was not reduced in either group (Table II).

There is a decrease in the daily consumption of beverages in subjects aged 15-16 years old (Table III).

Table I. Frequency of tooth brushing among schoolchildren (\%).

\begin{tabular}{|c|c|c|c|c|c|c|c|c|}
\hline & \multicolumn{2}{|c|}{ Baseline } & \multicolumn{2}{|c|}{$\begin{array}{c}1^{\text {st }} \mathrm{OH} \\
\text { education } \\
\text { lesson }\end{array}$} & \multicolumn{2}{|c|}{$\begin{array}{c}2^{\text {nd }} O H \\
\text { education } \\
\text { lesson }\end{array}$} & \multicolumn{2}{|c|}{$\begin{array}{c}3^{\text {rd }} \mathrm{OH} \\
\text { education } \\
\text { lesson }\end{array}$} \\
\hline & $\begin{array}{l}13-14 \\
\text { years }\end{array}$ & $\begin{array}{l}15-16 \\
\text { years }\end{array}$ & $\begin{array}{l}13-14 \\
\text { years }\end{array}$ & $\begin{array}{l}15-16 \\
\text { years }\end{array}$ & $\begin{array}{l}13-14 \\
\text { years }\end{array}$ & $\begin{array}{l}15-16 \\
\text { years }\end{array}$ & $\begin{array}{l}13-14 \\
\text { years }\end{array}$ & $\begin{array}{l}15-16 \\
\text { years }\end{array}$ \\
\hline$\geq 2$ times/day & 73.9 & 60.7 & 75.8 & 73.3 & 81.9 & 78.8 & 75 & 88.5 \\
\hline Once a day & 20.0 & 33.3 & 24.2 & 26.7 & 12.1 & 21.2 & 20.8 & 11.5 \\
\hline Several times/week & 1.5 & 3.0 & 0 & 0 & 3.0 & 0 & 4.2 & 0 \\
\hline 2-3 times a month & 4.6 & 3.0 & 0 & 0 & 3.0 & 0 & 0 & 0 \\
\hline
\end{tabular}

Table II. Frequency of biscuits/cakes consumption among schoolchildren (\%).

\begin{tabular}{|c|c|c|c|c|c|c|c|c|}
\hline & \multicolumn{2}{|c|}{ Baseline } & \multicolumn{2}{|c|}{$\begin{array}{c}1^{\text {st }} \mathrm{OH} \\
\text { education } \\
\text { lesson }\end{array}$} & \multicolumn{2}{|c|}{$\begin{array}{c}2^{\text {nd }} \mathrm{OH} \\
\text { education } \\
\text { lesson }\end{array}$} & \multicolumn{2}{|c|}{$\begin{array}{c}3^{\text {rd }} \mathrm{OH} \\
\text { education } \\
\text { lesson }\end{array}$} \\
\hline & $\begin{array}{l}13-14 \\
\text { years }\end{array}$ & $\begin{array}{l}15-16 \\
\text { years }\end{array}$ & $\begin{array}{l}13-14 \\
\text { years }\end{array}$ & $\begin{array}{l}15-16 \\
\text { years }\end{array}$ & $\begin{array}{l}13-14 \\
\text { years }\end{array}$ & $\begin{array}{l}15-16 \\
\text { years }\end{array}$ & $\begin{array}{l}13-14 \\
\text { years }\end{array}$ & $\begin{array}{l}15-16 \\
\text { years }\end{array}$ \\
\hline$\geq 2$ times/day & 9.1 & 3.3 & 30.3 & 6.7 & 30.3 & 18.2 & 17.6 & 21.9 \\
\hline Once a day & 24.2 & 36.7 & 33.3 & 33.3 & 33.3 & 24.2 & 23.5 & 12.5 \\
\hline Several times/week & 24.2 & 36.7 & 33.3 & 40.0 & 33.3 & 30.3 & 17.6 & 25 \\
\hline 2-3 times a month & 36.4 & 20.0 & 18.2 & 16.7 & 18.2 & 24.2 & 8.8 & 21.9 \\
\hline Never & 0 & 0 & 0 & 0 & 0 & 0 & 2.9 & 0 \\
\hline Missing & 3.0 & 3.3 & 3.0 & 3.3 & 3.0 & 3.3 & 29.4 & 18.8 \\
\hline
\end{tabular}


Table III. Frequency of carbonated beverages consumption by schoolchildren (\%).

\begin{tabular}{|c|c|c|c|c|c|c|c|c|}
\hline & \multicolumn{2}{|c|}{ Baseline } & \multicolumn{2}{|c|}{$\begin{array}{c}1^{\text {st }} \mathrm{OH} \\
\text { education } \\
\text { lesson }\end{array}$} & \multicolumn{2}{|c|}{$\begin{array}{c}2^{\text {nd }} \mathrm{OH} \\
\text { education } \\
\text { lesson }\end{array}$} & \multicolumn{2}{|c|}{$\begin{array}{c}3^{\text {rd }} \mathrm{OH} \\
\text { education } \\
\text { lesson }\end{array}$} \\
\hline & $\begin{array}{l}13-14 \\
\text { years }\end{array}$ & $\begin{array}{l}15-16 \\
\text { years }\end{array}$ & $\begin{array}{l}13-14 \\
\text { years }\end{array}$ & $\begin{array}{l}15-16 \\
\text { years }\end{array}$ & $\begin{array}{l}13-14 \\
\text { years }\end{array}$ & $\begin{array}{l}15-16 \\
\text { years }\end{array}$ & $\begin{array}{l}13-14 \\
\text { years }\end{array}$ & $\begin{array}{l}15-16 \\
\text { years }\end{array}$ \\
\hline$\geq 2$ times/day & 6.1 & 6.7 & 21.2 & 10.0 & 27.3 & 6.1 & 5.9 & 6.3 \\
\hline Once a day & 6.1 & 13.3 & 15.2 & 10.0 & 15.2 & 6.1 & 11.8 & 3.1 \\
\hline Several times/week & 9.1 & 23.3 & 21.2 & 10.0 & 18.2 & 27.3 & 23.5 & 18.8 \\
\hline 2-3 times a month & 51.5 & 30.0 & 24.2 & 40.0 & 30.3 & 33.3 & 23.5 & 25 \\
\hline Never & 27.3 & 0 & 15.2 & 0 & 6.1 & 0 & 5.9 & 25 \\
\hline Missing & 0 & 26.7 & 3.0 & 30.0 & 3.0 & 27.3 & 29.4 & 21.9 \\
\hline
\end{tabular}

Table IV. Knowledge regarding the role of fluoride in the toothpastes (\%).

\begin{tabular}{|c|c|c|c|c|c|c|c|c|}
\hline & \multicolumn{2}{|c|}{ Baseline } & \multicolumn{2}{|c|}{$\begin{array}{c}1^{\text {st }} \mathrm{OH} \\
\text { education } \\
\text { lesson }\end{array}$} & \multicolumn{2}{|c|}{$\begin{array}{l}2^{\text {nd }} \mathrm{OH} \\
\text { education } \\
\text { lesson }\end{array}$} & \multicolumn{2}{|c|}{$\begin{array}{c}3^{\text {rd }} \mathrm{OH} \\
\text { education } \\
\text { lesson }\end{array}$} \\
\hline & $\begin{array}{l}13-14 \\
\text { years }\end{array}$ & $\begin{array}{l}15-16 \\
\text { years }\end{array}$ & $\begin{array}{l}13-14 \\
\text { years }\end{array}$ & $\begin{array}{l}15-16 \\
\text { years }\end{array}$ & $\begin{array}{l}13-14 \\
\text { years }\end{array}$ & $\begin{array}{l}15-16 \\
\text { years }\end{array}$ & $\begin{array}{l}13-14 \\
\text { years }\end{array}$ & $\begin{array}{l}15-16 \\
\text { years }\end{array}$ \\
\hline Yes & 30.3 & 33.3 & 72.7 & 80.0 & 78.8 & 81.8 & 61.8 & 100 \\
\hline No & 69.7 & 66.7 & 27.3 & 20.0 & 12.1 & 18.2 & 5.9 & 0 \\
\hline Missing & 0 & 0 & 0 & 0 & 9.1 & 0 & 32.4 & 0 \\
\hline
\end{tabular}

Table V. Schoolchildren knowledge regarding steps of tooth brushing (\%).

\begin{tabular}{|c|c|c|c|c|c|c|c|c|}
\hline & \multicolumn{2}{|c|}{ Baseline } & \multicolumn{2}{|c|}{$\begin{array}{c}1^{\text {st }} \mathrm{OH} \\
\text { education } \\
\text { lesson }\end{array}$} & \multicolumn{2}{|c|}{$\begin{array}{c}2^{\text {nd }} \mathrm{OH} \\
\text { education } \\
\text { lesson }\end{array}$} & \multicolumn{2}{|c|}{$\begin{array}{c}3^{\text {rd }} \mathrm{OH} \\
\text { education } \\
\text { lesson }\end{array}$} \\
\hline & $\begin{array}{l}13-14 \\
\text { years }\end{array}$ & $\begin{array}{l}15-16 \\
\text { years }\end{array}$ & $\begin{array}{l}13-14 \\
\text { years }\end{array}$ & $\begin{array}{l}15-16 \\
\text { years }\end{array}$ & $\begin{array}{l}13-14 \\
\text { years }\end{array}$ & $\begin{array}{l}15-16 \\
\text { years }\end{array}$ & $\begin{array}{l}13-14 \\
\text { years }\end{array}$ & $\begin{array}{l}15-16 \\
\text { years }\end{array}$ \\
\hline Yes & 93.9 & 96.7 & 39.4 & 33.3 & 39.4 & 33.3 & 35.3 & 27.8 \\
\hline No & 6.1 & 3.3 & 60.6 & 66.7 & 60.6 & 66.7 & 64.7 & 72.2 \\
\hline
\end{tabular}

\section{Results regarding oral health knowledge} changes after every education lesson

Regarding the subjects' knowledge of fluoride role, initially about one-third knew this aspect $(30.3 \%$ for those aged 13-14 and 33.3\% for those aged 15-16) (Table IV). All 15-16 year-old students understood the role of Fluor and more than half $(61.8 \%)$ of the other age group (Table IV).

Before applying the oral health education lessons, the proportion of subjects who did not know the tooth brushing steps was overwhelming $(93.9 \%$ for those aged 13-14 and 96.7\% for those aged 15-16) (Table V).

\section{Discussion}

In terms of tooth brushing behavior, the results were better for the 15-16 years age group, the percentage of subjects who brushed their teeth at least 2 times a day increased and the number of those who brushed less than once a day decreased (Table I).
Concerning food behavior of cariogenic diet, the results were less encouraging, the frequent use of biscuits, cakes and beverages remains high and frequent, more than two times/day in both groups, especially in those of 13-14 years (Table II and III).

After the education lesson, the role of Fluoride in toothpaste is known by all 15- to 16-year-olds (Table IV). About one-third of 13-14-years old need to repeat the message in this respect.

Regarding the level of knowledge, the percentage of schoolchildren who know the correct brushing steps (the correct order of all stages for both groups, more for the 15-16 years) has significantly improved (Table V).

It is desirable to track in time to see to what extent the increase in the level of knowledge will be transposed into routine practice, and teenagers will have a correct brushing technique, behavior that can turn into a lifelong habit, since health patterns should established in adolescence or even earlier in order to continue in adult life [11]. 


\section{Conclusions}

Adolescents included in this study are informed about oral health, but this knowledge must be systematized in order to form accurate health behavior, correlated with the importance of disease prevention on improving the quality of life. Oral health behavior was improved by the experiential education lessons offered, especially on oral hygiene. There is a need of emphasis on the importance of noncariogenic diet and on regular dental check-ups. After having performed education lessons in schools, this study highlighted the need to implement such oral health programs to encourage children and adolescents to increase their knowledge and stimulate the correct hygiene and diet habits, thus contributing to the improvement and maintenance of oral health.

\section{Acknowledgements}

The Erasmus+ project "Youth Communitybased Oral Health Learning Model" 2015-2-R001KA205-013237 was co-funded by the European Union. The authors thank Procter \& Gamble Mkt Romania for the support of the study.

\section{References}

1. Petersen PE. The World Oral Health Report 2003: continuous improvement of oral health in the 21 st century--the approach of the WHO Global Oral Health Programme. Community Dent Oral Epidemiol. 2003;31 Suppl 1:3-24.

2. Kolb DA. Experiential Learning: Experience as the Source of Learning and Development (2nd Edition). Englewood Cliffs, N.J. Prentice-hall, 1984.

3. Tolvanen M, Lahti S, Poutanen R, Seppä L, Pohjola V,
Hausen H. Changes in children's oral health-related behavior, knowledge and attitudes during a 3.4-yr randomized clinical trial and oral health-promotion program. Eur J Oral Sci. 2009;117:390-397.

4. Hedman E, Gabre P, Birkhed D. Dental hygienist working in schools - a two-year oral health intervention programme in Swedish secondary schools. Oral Health Prev Dent. 2015; $13: 177-188$.

5. Dumitraşcu L. Schimbarea atitudinilor şi comportamentelor față de sănătatea orală [Changes of oral health attitudes and behaviors]. "Carol Davila" Publishing House, Bucharest, 2012.

6. World Health Organization. Oral health promotion: an essential element of a health-promoting school. Geneva: WHO, 2003.

7. Dumitrache AM, Sfeatcu IR, Buzea CM et al. Concepte şi tendinţe în sănătatea orală [Concepts and tendencies in oral health]. "Carol Davila" Publishing House, Bucharest, 2009.

8. Sfeatcu R, Dumitrache MA, Cărămidă M, Johannsen A, Perlea P. A pilot study on the effectiveness of a 2-year schoolbased oral health educational programme using experiential learning among adolescents. Int J Dent Hyg. 2019 Apr 3. doi: 10.1111/idh.12400. [Epub ahead of print]

9. Bucharest: Erasmus+ project: Youth Community-based Oral Health Learning Model, Ref. no: 2014-2-Ro01KA205-013237; Available from: http://com4you.ro

10. Angelopoulou MV, Oulis CJ, Kavvadia K. School-based oral health-education program using experiential learning or traditional lecturing in adolescents: a clinical trial. Int Dent J. 2014;64:278-284.

11. Singh A, Bassi S, Nazar GP, Saluja K, Park M, Kinra S, et al. Impact of school policies on non-communicable disease risk factors - a systematic review. BMC Public Health. 2017;17:292. doi: 10.1186/s12889-017-4201-3. 